Pamiętnik Literacki 2013, 2, s. 205-218
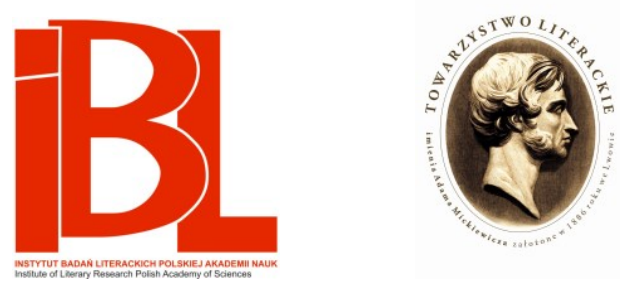

Prywatysta Witkiewicz

O maturze Stanisława Ignacego Witkiewicza

\author{
Tomasz Pawlak
}


Pamiętnik Literacki CIV, 2013, z. 2

PL ISSN 0031-0514

TOMASZ PAWLAK

(Warszawa)

\title{
PRYWATYSTA WITKIEWICZ
}

\author{
O MATURZE STANISŁAWA IGNACEGO WITKIEWICZA
}

W czerwcu 1903 18-letni Stanisław Ignacy Witkiewicz otrzymuje we Lwowie świadectwo dojrzałości. Jego ojciec, Stanisław Witkiewicz, pisze o tym do swojej siostry, Marii:

Więc Stasiek wrócił d o j r z ały - choć bardzo zielony - jak jego świadectwo. Rzeczywiście, jak się widzi rezultat tej pracy, tych czternastu egzaminów - to trzeba przyznać, że ludzkość jest w obłędzie! „Świadectwo dojrzałości”! Ja, który go nie mam, jestem zatem dotąd niedojrzały! ${ }^{1}$

Dotychczas niewiele było wiadomo o maturze Stanisława Ignacego Witkiewicza poza tym, że zdawał ją eksternistycznie we Lwowie, a jego wybitny ojciec, który nie uznawał nauki szkolnej, odnosił się do tego egzaminu krytycznie, czego dowodem przytoczony fragment listu.

W trakcie pracy nad edycją listów Witkacego do rodziny, przyjaciół i „wrogów” postanowiłem ustalić, w jakiej lwowskiej szkole podchodził do matury późniejszy autor Pożegnania jesieni. Wnikliwa lektura Listów do syna Stanisława Witkiewicza, łut szczęścia oraz ze wszech miar pożyteczna i godna wsparcia działalność bibliotek cyfrowych pozwoliły mi na dokonanie nie tylko odkrycia, w jakiej szkole świadectwo uzyskał, ale także, z jakich przedmiotów oraz - prawdopodobnie z jakim wynikiem! Takie odkrycia Janusz Degler nazywa „cudami św. Witkacego”. A zatem jak z tą maturą było?

Stanisław Witkiewicz ojciec rzeczywiście szkół nie kończył. Jego naukę $\mathrm{w}$ trzeciej klasie gimnazjum przerwało powstanie styczniowe, w którym młody Stalutek - jak na niego wołano - pomagał dorosłym. Za udział w powstaniu zesłano rodziców w sierpniu 1864 do Tomska, zezwalając, aby towarzyszyły im dwie córki i syn, Stanisław. Po klęsce zrywu narodowego przywilej nauki nie przysługiwał zesłańcom, a ponieważ majątek Witkiewiczów skonfiskowano, na edukację, choćby prywatną, nie było skąd brać. Dzięki zabiegom rodziny karę zesłania skrócono, ale przyszły malarz po powrocie do kraju nie uczęszczał już do gimnazjum. We wrześniu 1868 został przyjęty na podstawie wykonanego rysunku do Akademii Cesarskiej Sztuk Pięknych w Petersburgu. Atmosfera biurokratycznej

1 S. I. W it k i e w i c z, list do M. Witkiewiczówny, z 7 VI 1903. W: Listy. T. 1: Listy do Marii Witkiewiczówien i Jana Koszczyca-Witkiewicza, cz. 1 (w przygotowaniu). Dzieła zebrane. [T. 17]. 
i bezdusznej uczelni zniechęciła go wszakże do tej instytucji, przerwał naukę i w 1871 roku wyjechał do Monachium, gdzie wstąpił do Królewskiej Akademii Sztuk Pięknych ${ }^{2}$. Jednak tutaj również szybko się rozczarował i przyjął metodę swobodnego samokształcenia:

Sam dobierał sobie preceptorów, sam kierował swoją edukacją malarską i sam wyznaczał sobie lektury. Nawyk samouka znowu wziął górę nad rygorami systemu szkolnego. Druga z kolei akademia nie wydała temu zbuntowanemu i nieokiełznanemu Żmudzinowi żadnego świadectwa ani nie odznaczyła go żadnym medalem. Natomiast obie zaszczepiły w nim upartą awersję do szkół jako zakładów wychowawczych dla ludzi sztuki [...]. Będzie też zawsze -już jako aktywny krytyk - wyrażał swą niewiarę w skuteczność szkolenia artystów we wszelkich akademiach sztuk pięknych, walkę z profesorskimi autorytetami rozszerzy do walki z wszelkimi autorytetami w sztuce ${ }^{3}$.

Nie dziwi zatem, że z taką niechęcią oceni decyzję syna, gdy ten po latach postanowi zostać studentem Akademii Sztuk Pięknych w Krakowie ${ }^{4}$.

W roku 1890 Stanisław Witkiewicz przeniósł się wraz z rodziną do Zakopanego, aby leczyć gruźlicę. Miało to tę dodatkową zaletę, że mieszkanie tam było tańsze niż w Warszawie. Jednak nieustanne kłopoty materialne nie opuszczą już Witkiewiczów. Zalecany malarzowi pobyt na południu Europy wymagał nie tylko podjęcia pracy zarobkowej przez Marię Witkiewiczową, ale przede wszystkim wsparcia (czasem dyskretnego - ze względu na dumę chorego) rodziny, przyjaciół i wielbicieli autora literackiej relacji Na przetęczy.

A Staś? W Zakopanem ani gimnazjum, ani szkoły realnej (jeszcze) nie było. Kwestie materialne niewątpliwie miały pewien wpływ na to, że nie wysłano go do szkół w Krakowie lub we Lwowie. Koszty podróży i stancji mogły Witkiewiczów po prostu przerastać. Ojciec zadbał jednak o naukę syna. Pisał o tym po latach jego kuzyn, Jan:

Staś nie chodził do żadnej szkoły, gdyż w Zakopanem była wtedy tylko szkoła początkowa. Nauczyciel tej szkoły, jednocześnie pierwszy kustosz Muzeum Tatrzańskiego, p. Staszel, był pierwszym nauczycielem Stasia. Następnie kurs gimnazjalny przechodził [Staś] pod kierunkiem Mieczysława Limanowskiego, późniejszego geologa, profesora w Wilnie, wtedy jeszcze studenta we Lwowie 5 .

Stanisław Ignacy nie chodził zatem do szkoły, ale jej roczne programy przerabiał. Zdawał egzaminy co semestr w szkole realnej - czyli średniej z przewagą przedmiotów matematyczno-przyrodniczych - we Lwowie, dokąd jeździł z ojcem lub matką. Niewykluczone, iż w wyborze tamtejszej szkoły Witkiewiczowie kie-

2 Zob. Z. P i a s e c k i, Stanisław Witkiewicz. Młodość i wczesny dorobek artysty. Warszawa 1983.

3 M. O $1 \mathrm{~s} \mathrm{z} \mathrm{a} \mathrm{n} \mathrm{i} \mathrm{e} \mathrm{c} \mathrm{k} \mathrm{a,} \mathrm{Szkolne} \mathrm{peregrynacje} \mathrm{Stanisława} \mathrm{Witkiewicza.} \mathrm{„Miesięcznik} \mathrm{Literacki”}$ 1968, nr 1, s. 108.

4 O ideologicznym podłożu tej niechęci do szkoły, mającej związek z poglądami H. Spencera i F. Nietzschego - zob. B. D a n e k - Wo j n o w s k a, wstęp w: S. W i t k i e w i c z, Listy do syna. Oprac. B. D a n e k-Woj n ow s k a, A. M i c iń s k a. Warszawa 1969, s. 9-12. Dalej do tej pozycji odsyłam, umieszczając lokalizacje w nawiasach w tekście głównym; liczby po średniku wskazują datę listu (podaję tylko dzień i miesiąc, gdyż wszystkie listy pochodzą z 1903 roku).

J. Wi t k i e w i c z, Życiorys Stanistawa Ignacego Witkiewicza. W zb.: Stanisław Ignacy Witkiewicz. Człowiek i twórca. Księga pamiątkowa. Red. T. Kotarbiński, J. E. Płomieński. Warszawa 1957, s. 343-344. 
rowali się tym, że odwiedzając ją, mogli zatrzymywać się w Snopkowie pod Lwowem u cioci Teli (Tekli z Jankowskich Domaszewiczowej), siostry ciotecznej Marii Witkiewiczowej (,Rzeczywiście, co za dobry los, że macie tam takich kochanych ludzi jak Ciocia Tela i dwunastu dobrych Wujaszków, i ten Snopków zjego wiosną" 〈s. 94; $16 \mathrm{~V}\rangle)^{6}$.

Ojciec był zadowolony, że opresyjny system szkoły nie dotyczy jego jedynaka i że może on rozwijać swoje zainteresowania swobodnie, w kontakcie z uczonymi przebywającymi w Zakopanem. Znalazł się wśród nich, oprócz wymienionych Walerego Staszla i Mieczysława Limanowskiego, m.in. Władysław Folkierski, matematyk, fizyk, inżynier, który edukował Stasia w tej pierwszej dziedzinie. To o nim ojciec wspomina w liście z 28 V 1903: „Pójdę dziś do Ministra robót publicznych, żeby powiedzieć o doskonałej matematyce!” (s. 107)7.

Swoboda $\mathrm{w}$ nauce skonfrontowana $\mathrm{z}$ koniecznością przerobienia materiału szkolnego wymagała od Stasia dużej samodyscypliny. Z pewnością wykształciło to w nim pracowitość, która pozwoliła mu w późniejszych latach tak wiele zdziałać w literaturze, malarstwie, filozofii, publicystyce, krytyce. O codziennym reżimie dorosłego Witkacego - m.in. o ćwiczeniach porannych, o ablucjach, o lekturze przed śniadaniem - pisała we wspomnieniach jego żona, Jadwiga ${ }^{8}$.

Wróćmy jednak do samej matury Stanisława Ignacego Witkiewicza. Wyjazd jest szykowany od dawna, Staś uczy się do egzaminów, a pozostający jeszcze w Krakowie (gdzie m.in. hołubi przebywającą w tym mieście swoją dawną miłość - Helenę Modrzejewską ${ }^{9}$ ) ojciec pociesza go w kwietniu: „Wiem, że kujesz, i żal mi Ciebie. Ale spójrz na to inaczej. J e s te ś k u ty! Kute żelazo jest więcej warte od lanego" (s. 86; 26 IV).

6 Być może, wybór Lwowa (zamiast Krakowa) był także w pewnym stopniu spowodowany obawą przed ,zemstą" środowiska krakowskiego na synu autora Sztuki i krytyki u nas (1891; pierwodruk w „Wędrowcu”), w której S. Witk i ew ic z poddał surowej ocenie krakowską szkołę malarstwa z J. Matejką jako ówczesnym rektorem Akademii Sztuk Pięknych. O tym, że uczniowie Matejki pamiętali Witkiewiczowi ten cykl tekstów, pisała M. O $1 \mathrm{~s} \mathrm{z} \mathrm{a} \mathrm{n} \mathrm{i} \mathrm{e} \mathrm{c} \mathrm{k} \mathrm{a} \mathrm{(Dziwny} \mathrm{człowiek.}$ $\langle$ OO Stanistawie Witkiewiczu〉. Kraków 1984, s. 111;376, przypis 71).

7 W ładysław Folkierski (1841-1904) swoim życiorysem mógłby obdarzyć kilka osób. Wykształcony w Niemczech i Francji, przerwał naukę, aby wziąć udział w powstaniu styczniowym. Po jego upadku wrócił na studia do Paryża. W ich trakcie pracował też jako pedagog w polskiej szkole. Bronił Francji w wojnie z Prusami w latach 1870-1871, a w 1874 r. wyjechał wraz z innymi inżynierami do Peru, gdzie zasłużył się jako budowniczy mostów i kolei oraz jako badacz, wieloletni rektor uczelni i obrońca nowej ojczyzny, który fortyfikował jej porty. Zob. Słownik polskich pionierów techniki. Red. B. Orłowski. Katowice 1984. - W. i T. S 子 a b c z y ń s c y, Stownik podróżników polskich. Przedm. J. B a b i c z. Warszawa 1992. Folkierski wrócił do kraju w 1892 roku. W Galicji budował koleje, m.in. Stanisławów-Woronienka i Chabówka-Zakopane, oraz wodociąg przemysłowy w Kuźnicach. Co ciekawe, jednym z licznych zainteresowań inżyniera była astronomia. W Peru pomagał Amerykanom wznieść obserwatorium astronomiczne w Arequipie, sam także prowadził tam obserwacje. Pasja astronomiczna u Stanisława Ignacego mogła być przez Folkierskiego jeśli nie wzbudzona, to na pewno podtrzymywana.

8 J. W it k i e wi c zow a, Wspomnienia o Stanistawie Ignacym Witkiewiczu. Appendix w: S. I. W i t k i e w i c z, Listy do żony (1936-1939). T. 4. Przygot. do druku A. M i c iń s k a. Oprac., przypisy J. D e gle r. Warszawa 2012, s. 568-572. Dzieła zebrane. [T. 22]. Pierwodruk w zb.: Spotkanie z Witkacym. Materiały sesji poświęconej twórczości Stanisława Ignacego Witkiewicza (Jelenia Góra, 2-5 marca 1978). Oprac., red. J. D e g l e r. Jelenia Góra 1978, s. 81-85.

9 Zob. J. D e gle r, Helena Modrzejewska i Witkiewiczowie. „Pamiętnik Teatralny” 2009, z. $3 / 4$. 
Stasiowi we Lwowie będzie towarzyszyć matka. Zresztą wyprawa potrwa na tyle długo, iż zdoła ona przy okazji zrobić zakupy („Niech już Mama kupi sobie kalosze nowe, a dziecku buty" 〈s. 98; $17 \mathrm{~V}\rangle$ ) i ,uporządkować zęby” (s. 106; $27 \mathrm{~V}$ ). Ojciec uspokaja w liście wysłanym jeszcze z Krakowa, że o pieniądze na podróż (koniecznie drugą klasą! 〈s. 91; $4 \mathrm{~V}\rangle$ ) i wydatki na pobyt nie trzeba się niepokoić, bo dostanie honoraria za publikacje: „Zbliża się czas Waszego wyjazdu. Dudeczki będziemy mieli, bo na początek przyjdzie coś za Dziwnego człowieka - a potem za parę tygodni Przetęcz" (s. 87; 29 IV).

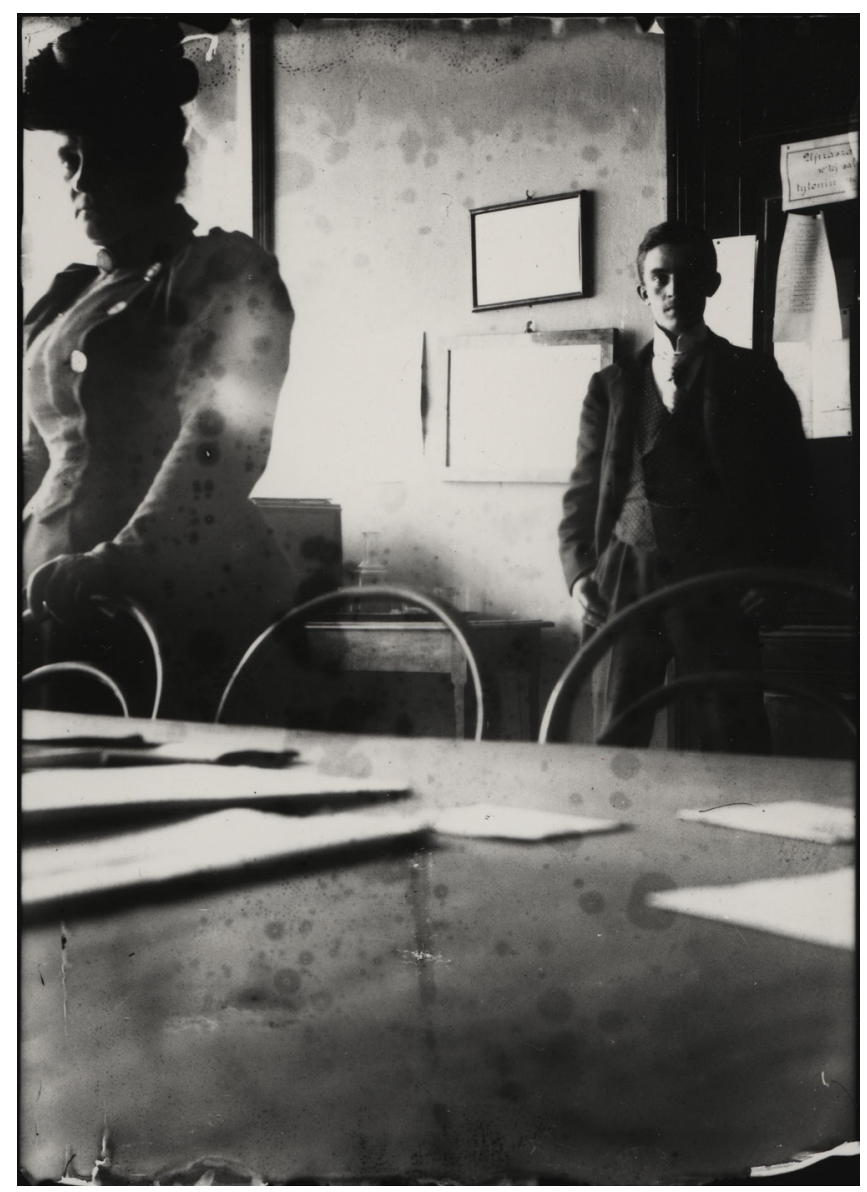

Stanisław Ignacy Witkiewicz z matką we Lwowie w okresie zdawania matury.

(Fotografia wykonana samowyzwalaczem przez Stanisława Ignacego Witkiewicza 〈1903〉. Z kolekcji Ewy Franczak i Stefana Okołowicza)

Staś z matką wyjeżdżają do Lwowa $3 \mathrm{~V}^{10}$, a już $5 \mathrm{~V}$ mają się zacząć egzaminy, bo $4 \mathrm{~V}$ ojciec pisze o trzech burzach, które ,czyniły cuda” w Tatrach: „Bardzo

${ }^{10}$ Chronologia wydarzeń na podstawie Listów do syna. 
żałowałem, że pewien znajomy malarz, utalentowany, choć młody i mający dojrzeć jutro między 8-mą rano a 4-tą po południu-że malarz ten tego nie widział" (s. 90) ${ }^{11}$. Emocje związane z egzaminami udzielają się nawet temu zagorzałemu przeciwnikowi szkoły. W regularnej korespondencji dopytuje się: „Cóż to to dziecku zrobili, co? Czy bardzo zmęczyli?” (s. 91; 11 V), „Więc co z Tobą się dzieje?” (s. 92; $12 \mathrm{~V}$ ). Dopomina się o częstsze listy, zapewnia, że jemu zdrowie służy, donosi o tym, co zdarzyło się u znajomych, co u „kociej rodziny" w domu i co robią jej członkowie (Markiza, Margrabina, Foka, której „dziecko nie wyżyło” $\langle$ s. 102; $24 \mathrm{~V}\rangle$, więc Sherlock ,zabrał się do ssania, co Foce szalenie się podobało. Oblizała go tak, że teraz jest biały jak śnieg" (s. 104; $26 \mathrm{~V}\rangle$ ).

W Zakopanem uczą się też do matury przyjaciele Stasia, bracia Lilpopowie (Oro i Władysław, zwany Radcą lub Adziem). Ich egzaminy musiały zaczynać się później, bo Witkiewicz z humorem donosi w kolejnych listach:

U Lilpopów kucie. Radca szczegółowo wypytuje. Oro ze zdziwieniem wyziera z greckich tekstów. [s. 92; $11 \mathrm{~V}]$

Chłopcy kują zawzięcie. Wiadomości o Tobie słuchają chciwie i czytają w nich swoją przyszłość. [s. 95; $16 \mathrm{~V}$ ]

Radca kuje tak, że się mruczenie jego rozlega po lesie. Pomimo to naradza się z biegłymi nad tenisem na polance. Oro wygląda jak potworek Böcklina nastawiający uszu z morza. [s. 100; $22 \mathrm{~V}]$ $30 \mathrm{~V}]$

Chłopcy naturalnie kują. Wczoraj radca już się tak przekuł, że leżał bez ducha. [s. 108;

Atmosfera niepokoju o wynik egzaminów syna sprawia, że ojciec dodaje obszerny fragment „o samouctwie i systemie szkolnym” do publikowanego we fragmentach w „Tygodniku Ilustrowanym” Dziwnego człowieka, który ukaże się we Lwowie jeszcze w tymże 1903 roku $^{12}$. Po napisaniu mini-eseju o szkodliwości szkoły (,pastwiłem się nad maturą”) Witkiewicz niecierpliwie wygląda wieści o tematach maturalnych: „Czekam wiadomości, co się tam z dzieckiem działo - co tam było w tej tajemniczej kopercie. Czy parabola, psiakrew?" (s. 92; 12 V).

$\mathrm{W}$ dniu następnym notuje:

${ }^{11}$ Nie są to jednak egzaminy maturalne, ponieważ w 1903 r. pisemna matura rozpoczynała się 11 V. Zob. „Czas” 1903, nr 55, z 9 III, s. 2.

12 Pisze o tym w liście z 11 V (s. 91). Oto fragment ustępu o „szkolarstwie” (S. W i t k i e w i c z, Dziwny człowiek. Lwów 1903, s. 24-25): „W naszych czasach - może trochę dawniej - wynaleziono sposoby zabijania samodzielnej przedsiębiorczości umysłu, łamania i rozluźniania energii twórczej, stawiając jako jedyny i ostateczny cel do osiągnięcia: ś w i a d e c tw o d oj r załośc i! Nie nauka, nie wiedza, nie rozwój talentu, nie cnota - ś w i a d e ctwo d ojr zało ści! Ta szkoła, której się zdaje, że Grecy i Rzymianie byli w dziejach ludzkości tym, czym byli, dlatego że mówili po grecku i po łacinie; ta szkoła, która trzyma na obroży pięciu przynajmniej gramatyk przez szereg lat umysł dziecka i umysł człowieka dorastającego; ta szkoła, którą żeby raz skończyć, trzeba skończyć połowę prawie przeciętnego życia w ciężkiej pracy, napięciu nerwów i wyczerpaniu, bez żadnej korzyści, bez żadnej zdobytej umiejętności; ta szkoła zjada tyle sił i życia, że tylko niesłychanie silne natury mogą się po niej odgiąć i stać się jeszcze samodzielnymi i energicznymi ludźmi, których wytwórczość będzie odpowiadać rzeczywistej możności ludzkiej natury. System szkolny bierze dziecko w szóstym roku życia i puszcza dwudziestoletniego człowieka, po czternastu latach ciężkich robót - z e ś w i adectwem dojrzałości w kieszeni i duszą naderwaną, przepojoną wiarą w patenty, miejsca, stanowiska, kariery ostawione przywilejami, wynikającymi z zakończenia szkoły - ze zdania matury". 
Mam kartkę Mamy! Historyczny rozwój powieści polskiej! Cóż Ty, biedaku, z tym zrobiłeś? Moja Ziabo! Całuję Ciebie - trzymaj się tylko zdrowo i nie dawaj się historycznym rozwojom! [s. 93]

Najwyraźniej młody maturzysta pomagał innym, ponieważ w liście do syna Witkiewicz komentuje:

Jeżeli byłeś źródłem mądrości dla reszty więźniów, to chyba miałeś dość na własną potrzebę. Temat był dla Chmielowskiego czy Brücknera i nie mogę sobie wyobrazić, co Dziecko z tego zrobiło i od jakich czasów zaczęło? Jeżeli z fizyki nie zdasz - trzeba będzie Limanika powiesić za pasek, którym spina teraz swoją talię obwiniętą w flanelową koszulę ${ }^{13}$.

W następnych dniach widać już pewne uspokojenie nastrojów:

Wartko i intensywnie idzie ta matura. Bądźcie tylko zdrowi - reszta będzie, jako będzie.

Wyobrażam sobie to wszystko - jak dziecko siedzi pod kluczem i jak pisze, podnosząc od czasu nieprzytomne oczy. [s. 93; $15 \mathrm{~V}$ ]

Uspokojeniu sprzyja także list od syna z relacją z egzaminu (niezachowany, niestety, jak prawie cała korespondencja Stanisława Ignacego z ojcem ${ }^{14}$ ), który Witkiewicz kwituje słowami:

No i tak nawet bajeczna i nieprawdopodobna rzecz, jak matura - jednak „odchodzi”! Bon! Bardzo mi się podoba Twój opis samego procesu dojrzałości. [s. 94; 16 V]

\section{Egzaminy pisemne kończą się $16 \mathrm{~V}$. Ojciec podsumowuje je następnego dnia komentarzem:}

A więc koniec z piśmienną. Bon! I nie byłoby w tym nic złego, i nawet czasem dobrze jest musieć wykrzesać taką energię gdzieś w świat - żeby - żeby nie ten cały podstęp oszukaństwa, ten cały fałsz, który się bierze ze strony zabawnej $\langle$ ? $\rangle$, a w którym tkwi wyraz całej potworności dzisiejszej szkoły i pojęć o zadaniach wychowania. Odbądź to, ale nie zapominaj. Trzeba, żeby nowe pokolenia dążyły do przeprawy tego zła przez pamięć, że ich dusza była męczona i poniżana.

Mój Stary! Ja myślę, że wszystko zdasz - że będzie dobrze. [s. 96; 17 V]

Akurat wtedy ukazuje się w „Tygodniku Ilustrowanym” artykuł Józefa Kallenbacha o młodości Zygmunta Krasińskiego, obejmujący m.in. omówienie jego egzaminu dojrzałości. Witkiewicz donosi synowi i żonie tego samego dnia, w którym dokonał ,podsumowania”:

Dziwnym trafem ostatni nr „Tyg[odnika] Il[ustrowanego]” zawiera wspomnienia Zygmunta Krasińskiego i opis jego matury. 4 lipca 1827 siedział w liceum od 6-tej rano do 4-tej po południu i pisał ćwiczenia łacińskie. Nazajutrz od 6-tej rano do 6-tej wi e c zór! pisał „robotę polską”: Wykazać niedostateczność prawideł moralności z samego rozumu wyptywających i wskazać wyższość zasad moralności chrześcijańskiej! (Krasiński miał 15 lat.) Potem

${ }^{13}$ Cyt. za: Z. P i a s e c k i, Stanisław Witkiewicz w kregu ludzi i spraw sobie bliskich. Szkice nie tylko biograficzne. Opole 1999, s. 245 (rozdz. 9: Nieopublikowane listy Stanistawa Witkiewicza do syna - list z $14 \mathrm{~V}$ ). Nie wiadomo, o jakim egzaminie z fizyki mowa, za którego wynik odpowiedzialność miał ponieść Limanowski - Limanik. Nie był to egzamin maturalny (zob. dalej o zadaniach maturalnych).

${ }^{14}$ Cała znana obecnie korespondencja S. I. W i t k i e w i c z a z ojcem znajduje się w przywoływanym już tomie Listów. 
francuski, niemiecki. Wszystko odbywało się pod surowym nadzorem ${ }^{15}$. Krasiński tak opisuje w liście do Ojca: „Czarownik (pewno pedel) ${ }^{16}$ kilka razy przychodzi na dzień do nas, zagląda pod stoliki, czy słowników lub książek nie mamy. Ciągle zaś przy nas siedzi profesor. Nie wolno ani słowa gadać jeden do drugiego lub się radzić, jednak nie zachowują tego przepisu, bo się śmieją, gadają i krzyczą, i nie tak to jest nudne, j a k by mo gło b y ć”. Słowem, od 76 lat nie zmieniło się nic na jotę - na kreseczkę! Krasiński pisze dalej: „Dużo mam bardzo do roboty. Cały dzień siedzę w klasie, a wieczorem pracuję, osobliwie nad matematyką".

Zupełna parafraza Waszych listów - tylko zadany temat inny i pewno profesorowie dziś lepsi ludzie, którzy nie wyzyskują na niekorzyść dzieci wszystkich wad systemu. [s. 97-98; $17 \mathrm{~V}]$

Po skończeniu części pisemnej następuje kilka dni odpoczynku dla Stasia, który jednak zdaje się odczuwać zmęczenie psychiczne i brak zadowolenia z odniesionych już sukcesów, czego dowodzi list ojca:

Mój drogi Staruszku!

Nic to! Wróci Ci i ś wi a d o m a radość życia. Takie usposobienia przychodzą czasem wskutek wysiłku, jaki człowiek robi dla osiągnięcia celów, których nie rozumie znaczenia, a potrzeby nie odczuwa - więc nie ma tej zgodności duszy z tym, co osiągnął. Może i z Tobą tak jest. Cele matury, spowiedzi - są Ci dalekie, a wysiłek duszy dla ich osiągnięcia znaczny, więc się czujesz próżny i wypompowany. Ale to przejdzie. Odprostujesz się. To nie jest jeszcze tak gnębiące, ,jak by mogło być". [s. 102; $24 \mathrm{~V}$ ]

Fragment ze wzmianką o spowiedzi pozwala lepiej zrozumieć ustęp z listu wcześniejszego o dwa dni:

Bardzo mi się podoba ten Wasz staruszek ksiądz. To ten dobry typ polskiego księdza, w którym jest więcej chrześcijanina niż katolika, a nic ultramontanizmu ${ }^{17}$. [s. 100; $\left.22 \mathrm{~V}\right]$

Obowiązek spowiedzi (niewykluczone, iż połączonej z egzaminem z katechi$z u^{18}$ ) mógł być dla Stanisława Ignacego trudny, zważywszy, że jeszcze na początku przygody ze szkołą, gdy zdawał w 1897 roku do drugiej klasy szkoły realnej, jego ojciec pisał do rodziny:

Uczy się, biedactwo, szkolnej sieczki. W pewnych kierunkach robi postępy - ale katechizm idzie trudno. Bo też równie czegoś głupiego jak tutejszy katechizm świat nie widział.

15 Witkiewiczowi nie odpowiadało, że w oryginale było: ,pod surowym n a p o z ó r [podkreśl. T. P.] nadzorem" (J. K a 11 e n b a c h, Z młodych lat Zygmunta Krasińskiego. Studium psychologiczne. Cz. 2. „Tygodnik Ilustrowany” 1903, nr 20, z 16 V, s. 385).

${ }^{16}$ Uwaga w nawiasie pochodzi od S. Witkiewicza.

17 „Ultramontanizm” - tu w znaczeniu: klerykalizm. Od nazwy gorliwych zwolenników papieża, chcących całą władzę w Kościele katolickim przenieść do Rzymu (a więc za góry - ultra montes). Zob. M. Arct, Stownik wyrazów obcych. 33000 wyrazów, wyrażeń i przysłów cudzoziemskich. Pochodzenie wyrazów i etymologię oprac. H. U ł a s z y n. Wyd. 13. Warszawa 1935, s. 382.

${ }_{18}$ Nie był to jednak egzamin maturalny, ponieważ w pracy Chrześcijaństwo i katechizm (Lwów 1920, s. 1. Pierwodruk 〈z podtytułem O nauce religii w szkołach galicyjskich $\rangle$ : „Reforma Szkolna” 1904 〈cz. 1〉, 1913 〈cz. 2〉) S. W it k i e w i c z tak zaczyna krytykę nauczania religii w szkołach: „W każdej prawie sesji parlamentu przy rozprawie nad budżetem oświaty posłowie któregoś z odłamów partii konserwatywnej stawiają żądanie zwiększenia ilości godzin wykładów nauki religi w szkołach średnich, uzasadniając żądanie to coraz widoczniejszym upadkiem religijności wśród młodzieży. Inni, jak pewien ksiądz na zjeździe nauczycieli szkół średnich we Lwowie, żądają ostrzejszego przymusu dla młodzieży, żą daj ą zaprowadzeni a e gzaminu z religii przy maturze". 
Kujemy ze Staśkiem katechizm i gramatykę ${ }^{19}$.

Wreszcie przychodzi termin kolejnych egzaminów, 25 V. Dzień wcześniej Staś dostaje słowa wsparcia: „Więc na jutro walka - będę z Tobą - będę myślał o dziecku i jestem pewny, że Ci się nic nie stanie" (s. 103).

Witkiewicz dosyła pieniądze i następnego dnia pisze do żony i syna:

Więc w tej chwili dziecko jest żyłowane przez „kapłanów nauki”. Może i to przejdzie ,jako strzała i jako ptak na powietrzu” ${ }^{20}$. Kto może obciąć? Flach i geometria? Bo więcej chyba nikt.

$[\ldots]$

Całuję Twoje ręce i Synka wymiętoszonego przez Flacha do serca tulę. [s. 103-104; 25 V]

I tegoż dnia osobny list kieruje do syna:

Syneczku drogi! Teraz Cię biorą ,na tiortiury”. Oby Ci się powiodło, a w każdym razie zachowaj dobry duch. Bardzo - bardzo serdecznie...

Przerwał mi z rana pisanie p. Zaborowski - teraz już piąta i telegramu Waszego czekam z wielkim upragnieniem. Jak tam idzie? Czy bardzo dziecko żyłują i czy Ślusarz 〈?〉 nie narobił Wam biedy? [s. 113] $]^{21}$

Nie jest to jeszcze część ustna samego egzaminu dojrzałości, ale raczej poprawka (lub inny zaległy egzamin), ponieważ ojciec $27 \mathrm{~V}$ notuje:

Więc już odrobiona sprawa, która dziecku najwięcej pesymizmu napędzała. Czekam szczegółów tej kampanii. Czy dziecko przed maturą musi kuć jeszcze - czy będzie mogło odpocząć? Czy z historii do matury popuszczą? [s. 106]

W następnym liście zdradza mimochodem, komu w rodzinie najbardziej zależało na maturze, i po raz kolejny broni podjętej dawno decyzji o zdawaniu egzaminów tylko eksternistycznie:

Robisz na mnie wrażenie dojrzewającego ananasa! Rozumiesz, jak się cieszę, żeś przebrnął te progi, i wyobrażam sobie, jak to musi cieszyć Mamę. Naturalnie, że ludzie, którzy stosują ten system, są odeń o wiele lepsi. Żeby nie to, każdy taki jak Ty byłby zduszony w oczkach tej fatalnej sieci. [s. 107; $28 \mathrm{~V}$ ]

Przez kilka dni Witkiewicz nie wspomina już w listach o egzaminach. Pojawia się w nich osoba (Birówka? - edytorki listów nie były pewne odczytania), która

${ }^{19}$ Cyt. za: A. M i c iń s k a, Istnienie Poszczególne: Stanisław Ignacy Witkiewicz. Oprac. J. D e g 1 e r. Wrocław 2003, s. 42 (listy z 2 V i z 27 VI 1897).

20 Cytat z P. Skargi, ale kto wie, czy Witkiewicz nie zapamiętał tych słów z publikowanych od 1876 r. (najpierw w „Gazecie Polskiej”) Listów z podróży do Ameryki H. S i e n k i e w i c z a -przyjaciela i współwielbiciela H. Modrzejewskiej. Sienkiewicz relacjonuje swoją podróż, jeszcze w Europie (cytuję za wydaniem XX-wiecznym - Pisma wybrane. T. 4. Wyd. 3. Warszawa 1989, s. 21): „Gdy pociąg ruszył, obróciłem się, by przesłać ostatnie pożegnanie Belgii, temu krajowi, dla którego niepodobna nie czuć sympatii i o którym ile razy pomyślę, tyle razy pamięć przywodzi mi słowa Skargi, których część już przytoczyłem wyżej: »Siejba była w płakaniu, ale żniwo w weselu; niedola ich minęła jako strzała $\mathrm{i}$ jako ptak na powietrzu, a rozkosze jakby morze nieprzebrane trwają «".

${ }_{21}$ List błędnie datowany na 8 VI - Witkiewicz napisał tylko: „Poniedziałek”. Za datą $25 \mathrm{~V}$ przemawia to, że wtedy właśnie Stanisław Ignacy zdawał kolejny ważny egzamin. 8 VI już był po maturze, o czym wspominał Witkiewicz ojciec w cytowanym na początku liście do siostry z 7 VI (zob. przypis $1 \mathrm{w}$ niniejszym artykule). 
pomaga Stanisławowi Ignacemu, ale nie wiadomo, czy pomoc ta dotyczyła nauki, czy też raczej zdrowia, bo ono akurat zaczęło Stasiowi szwankować:

Jeżeli Birówka 〈?〉 Ci pomoże, to myślę, że już żadne nie spotka Cię „obcięcie”, sam spadniesz z drzewa wiedzy jako dojrzały ananas. [s. 110; $31 \mathrm{~V}$ ]

Moja Ziabo, bądź zdrów i aby Cię Birówka 〈?〉 nafaszerował odpowiednio. [s. 111;2 VI]

Jeszcze następnego dnia, 3 VI, ojciec dość tajemniczo pisze do syna: „Już wiem: »Nic, nic z tego nie będzie, źle, obciąłem się!«Bon! Poczekaj Pan, cóż potem będzie!"” (s. 112).

Biorąc pod uwagę, że Stanisław Ignacy jednak maturę zdał, a egzaminy ustne zaczęły się $4 \mathrm{VI}^{22}$, przypuszczać można, iż ów fragment nie był odzwierciedleniem rzeczywistości. Na tej notce korespondencja ojca z synem się urywa ${ }^{23}$, a kolejny list pochodzi z 24 VI, gdy Staś jest już w drodze na zasłużone wakacje - przez Podole na Litwę.

W dopowiedzeniu losów matury Stanisława Ignacego pomaga pewien z pozoru nudny (jak matura?) dokument: Trzydzieste sprawozdanie dyrekcji C. K. Wyższej Szkoty Realnej we Lwowie za rok szkolny $1903^{24}$. Widać, że twórcy tego sprawozdania musieli być świadomi jego efemeryczności, postanowili bowiem zaopatrzyć je w część dydaktyczną Nauka o formach języka francuskiego, którą „ułożył prof. Paweł Postel", a która była skróconą wersją gramatyki języka francuskiego w autorskiej edycji na potrzeby uczniów szkół realnych. Po 21 stronicach o liczebnikach, koniugacjach etc. dociera czytelnik do Statystyki zakładu. A wszystko to dotyczyło właśnie (nietrudno się domyślić) szkoły realnej, w której Staś zdawał maturę. We Lwowie - jak czytamy - do 1903 roku funkcjonowała tylko jedna szkoła realna (to ówcześnie normalna sytuacja w Galicji - zdecydowanie więcej istniało tam gimnazjów):

Jego Ces[arska] i Król[ewska] Apostolska Mość raczył najwyższym postanowieniem z dn[ia] 9 maja 1903 zezwolić na utworzenie z początkiem r[oku] szk[olnego] $1903 / 4$ II. państwowej szkoły realnej we Lwowie.

Z początkiem r. szk. 1903/4 zostanie obsadzona posada Dyrektora i pięciu nauczycieli rzeczywistych w nowo utworzonej II. szkole realnej lwowskiej.

Od r. 1856 istniała we Lwowie tylko j e d n a szkoła realna państwowa, jednak z powodu ciągle wzmagającej się frekwencji uczniów okazała się potrzeba utworzenia odrębnej fi 1 i i tego zakładu, ponieważ w gmachu głównym przy ul. Kamiennej 2 zabrakło potrzebnych ubikacji.

W r. szk. 1899/900 mieściła się filia w realności 1[okalu] 16 ul. Szeptyckich, miała 4 klasy niższe i 155 uczniów $^{25}$.

Zainteresowanych historią tejże placówki oświatowej oraz kroniką szkolną,

${ }^{22}$ Zob. „Czas” 1903, nr 55, s. 2.

${ }^{23}$ List ten, analogicznie do listu z $25 \mathrm{~V}$, powinien być datowany raczej na $27 \mathrm{~V}$.

${ }^{24}$ Zob. Podkarpacka Biblioteka Cyfrowa (http://www.pbc.rzeszow.pl/dlibra/plain-content?id=4644, data dostępu: 22 V 2013), dokument Biblioteki Uniwersytetu Rzeszowskiego.

${ }^{25}$ Trzydzieste sprawozdanie dyrekcji C. K. Wyższej Szkoły Realnej we Lwowie za rok szkolny 1903. Lwów 1903, s. 66. W roku 1920 szkoła ta została przekształcona w I Gimnazjum Męskie (typu matematyczno-przyrodniczego) im. M. Kopernika - zob. Spis nauczycieli szkół wyższych, średnich, zawodowych, seminariów nauczycielskich oraz wykaz zakładów naukowych $i$ władz szkolnych. Red. Z. Z a g ó r o w s k i. Lwów-Warszawa 1924, s. 306. 
a także programem zajęć, odsyłam do cytowanego dokumentu ${ }^{26}$. Skupmy się teraz na kwestiach najważniejszych, czyli na prawdopodobnych nauczycielach i egzaminatorach Stasia oraz, przede wszystkim, na tematach maturalnych.

Dyrektorem szkoły był cesarsko-królewski radca rządu, doktor filozofii Teofil Gerstmann, który uczył historii powszechnej ${ }^{27}$. Czyżby to o nim Witkiewicz pisał: „Odpowiedź Radcy Niemcowi - słuszna. A czy do Schopenhauera przyznałeś się?” (s. 93; $12 \mathrm{~V})^{28}$. W zakładzie głównym pracowali także m.in. wspominani w listach ojca Józef Flach (doktor filozofii, dydaktyk języka niemieckiego, od 1 VII 1902 z tytułem profesora) ${ }^{29}$ i ksiądz Jan Ślósarz (doktor teologii, uczył religii rzymskokatolickiej, ale był też autorem powszechnego w Galicji podręcznika do katechizmu dla szkół $)^{30}$. Stąd można wnioskować, że Stanisław Ignacy był egzaminowany w placówce przy ul. Kamiennej 2 (co zresztą potwierdza spis uczniów). Nie wymieniony z nazwiska potencjalny „obcinacz” z geometrii to Franciszek Berger ${ }^{31}$, dydaktyk rysunków geometrycznych (przy asyście Zygmunta Piechórskiego). Ksiądz, o którym pisał zatroskany ojciec, to zapewne Jan Kiernicki. Niewykluczone, że to on spowiadał Stanisława Ignacego, bo raczej nie chodziło o ultramontanistę Ślósarza.

Nie należał do grona pedagogicznego wzmiankowany w liście ojca do syna Grillpaser: „Ale że Grillpaser 〈?〉 zemścił się na Tobie za syntezę, która się skończyła w fotelu!" (s. 107; 28 V). Wyjaśnił to już jednak - w rozprawie o źródłach dramatu W małym dworku - Degler: szło o Franza Grillparzera (1791-1872), poetę, dramaturga i prozaika austriackiego ${ }^{32}$. Być może, do jego popularnej wówczas

${ }^{26}$ Atmosferę szkoły galicyjskiej z tego okresu zawarł E. Z e g a d ł o w i c z w powieści Zmory. Kronika z zamierzchtej przeszłości (Oprac. M. W ó j c i k. Wrocław 2006. Pierwodruk: Warszawa 1935) - z czytelnym (co przyczyniło się do skandalu wokół dzieła) kluczem personalnym.

27 Te ofil Gers tmann (1843-1907)-pedagog i publicysta. Zob. R. S k u l s k i, Gerstmann Teofil. Hasło w: Polski stownik biograficzny. T. 7 (1948-1958). Pozytywnie o Gerstmannie (znacznie mniej o ks. Ślósarzu oraz kilku innych nauczycielach) pisał uczeń szkoły realnej we Lwowie z tamtych lat, A. U z i e m bło (Wspomnienia lwowskie. Oprac., red. D. M a c i a k. Z fragmentów zestawiła A. U z i e m bło. „Przegląd Wschodni” 2001, z. 2, s. 483-486).

${ }_{28}$ Nauczyciela o nazwisku Niemiec w spisie brak, ale, oczywiście, mogło chodzić o któregoś z germanistów. Wzmianka o Schopenhauerze odnosi się do napisanej przez Stasia w grudniu 1902 rozprawki Filozofia Schopenhauera i jego stosunek do poprzedników, którą w roku następnym włączył on do pracy filozoficznej pt. Marzenia improduktywa. (Dywagacja metafizyczna) - zob. S. I. W it k i e w i c z, „Pojęcia i twierdzenia implikowane przez pojęcie Istnienia” $i$ inne pisma filozoficzne (1902-1932). Oprac. B. M i c h a 1 s k i. Warszawa 2002, s. 25-30. Dzieła zebrane. [T. 13]. Zob. też notę wydawniczą (ibidem, s. 467-474). .

29 J ó z e f F l a c h (1873-1944) - krytyk literacki i teatralny, publicysta, pedagog, germanista. Współpracownik „Przeglądu Polskiego”, w którym publikował recenzje teatralne i literackie. Zob. A. K l e c z k o w s k i, Flach Józef. Hasło w: Polski słownik biograficzny, t. 7.

${ }^{30}$ J a n Śló s a r z (1850-1917) - kanonik, prałat, docent. Zob. Polski słownik biograficzny, lista haseł planowanych, dostępna na stronie: http://www.psb.pan.krakow.pl/news/Szu-S_lista_hasel. doc, s. 51 (data dostępu: $30 \mathrm{~V}$ 2013).

${ }^{31}$ Franciszek Berger (1874-?) - profesor matematyki. Zob. Spis nauczycieli szkót wyższych, s. 306.

32 J. D e g 1 e r, W laboratorium Czystej Formy, czyli o nie dostrzeżonych źródłach ,W małym dworku”. Rozprawka w czterech i pót częściach, z Prologiem, Epilogiem i trupami. W zb.: Witkacy. Życie i twórczość. Materiały sesji poświęconej Stanisławowi Ignacemu Witkiewiczowi z okazji 55. rocznicy śmierci. (Muzeum Pomorza Środkowego, Stupsk, 16-18 września 1994). Red. ... Wrocław 1996, s. 125. 
twórczości Staś choć raz nawiązał w trakcie swych wielu egzaminów (przypomnijmy, ojciec naliczył ich 14 !) ${ }^{33}$.

Wróćmy zatem do samej matury. Tematy części pisemnej podzielono na trzy „oddziały”: A, B, C. Dzięki trosce ojca i powtórzeniu w liście tematu z języka polskiego (Historyczny rozwój powieści polskiej) zadanie jest ułatwione i można prześledzić w Oddziale $C$ wszystkie zagadnienia, z którymi miał do czynienia Stanisław Ignacy:

Z języka polskiego: Podać w zarysie historię powieści w literaturze polskiej.

$\mathrm{Z}$ języka niemieckiego: 1. Ludwig XIV. in der Geschichte der europäischen Staate in der Kultur und Kunst. 2. Przekład z języka niemieckiego na język polski: Petelenz-Werner, Lesebuch, f. d.[...] VIII. K1. str. 13.

$\mathrm{Z}$ języka francuskiego: Przekład z języka francuskiego na język polski: Amborski, Appendice, str. 69.

Z matematyki: 1. Wyznaczyć postać i położenie linii krzywej, oznaczonej równaniem: $16 x^{2}+9 y^{2}+16 x-6 y+1=0$, i obliczyć pole nią ograniczone.

2. Procent składany. Dług $15000 \mathrm{~K}$ wypożyczony na 10 lat na procent składany $3 \%$ spłaca dłużnik w pięciu ostatnich latach w równych ratach rocznych z dołu. Ile wynosi jedna rata.

3. Ściany równoległościanu są rombami; z których każdy ma po dwa kąty o wielkości 13546'48". Obliczyć nachylenie co dwóch ścian.

$\mathrm{Z}$ geometrii i rysunków geometrycznych: 1 . Wyznaczyć na prostej $(x=2, y=1, z=0) b$ $(6,4,5)$ punkt równo oddalony od $[\ldots]$ i płaszczyzny $A(7,6,5)$.

2. Na półkuli pustej, spoczywającej na $R$ o danym środku $m(5,5),(6,5),(5,5)$, położono prostą nieograniczoną $c(0) 2,5,5) d(12,8,5,5)$. Wykreślić wszystkie występujące cienie, przyjmując, że rzuty promienia świetlnego nachylone są do $O X$ pod kątem $45^{\circ}$.

3. Płaszczyzny poziomej rzutów $R_{1}$ dotyka się stożek obrotowy prost $[. .$.$] tworzącą t=7 \mathrm{~cm}$, nachyloną do $O X$ pod kątem $60^{\circ}$; promień podstawy $r=2,5 \mathrm{~cm}$. Przedstawić ten stożek w rzutach prostokątnych i do niego przez punkt zewnętrzny $a$ poprowadzić płaszczyzny styczne ${ }^{34}$.

Część ustna egzaminu dojrzałości odbywała się pod przewodnictwem „delegata c. k. Rady Szkolnej krajowej p. Michała Rembacza ${ }^{35}$, dyrektora c. k. szkoły realnej tarnopolskiej" od 4 do 16 VI $^{36}$. Niestety, w dokumencie nie znajdziemy już tematów tej części.

Pozostaje pytanie o wyniki egzaminu Stanisława Ignacego. Świadectwa z wyróżnieniem nie zdobył. Dostało je tylko 6 uczniów (z 46, którzy zdali). Na pierwszym miejscu był książę Leon Sapieha, późniejszy poseł na Sejm ${ }^{37}$. Witkiewicz

${ }^{33}$ Niewykluczone, iż reminiscencje tego fragmentu egzaminu dojrzałości S. I. W i t k i e w i c z zawarł w polemice z K. Irzykowskim (Beznadziejne porachunki z niepowrotnej przeszłości. 〈Wstęp do krytyki ,,Walki o treść” Karola Irzykowskiego . W: ,,Teatr” $i$ inne pisma o teatrze. Oprac. J. D eg 1 e r. Warszawa 1995, s. 350-351. Dzieła zebrane. [T. 9]): „Potem przeczytałem Irzykowskiemu, wbrew jego woli, mimo krzyków i protestów, sztukę moją pt. Janulka, córka Fizdejki, a gdy oświadczył, że nic nie rozumie i że wobec tego jest to zapewne zupełny nonsens (wszyscy, którzy u nas nie rozumieją rzeczy nie mającej za sobą jakiejś zagranicznej najlepszej sankcji, twierdzą to samo), opowiedziałem mu sztukę »własnymi słowami«, jakbym zdawał przy maturze z lektury domowej”.

${ }^{34}$ Trzydzieste sprawozdanie [...], s. 52. Niestety, skan tej stronicy miejscami nieczytelny przy zgięciu kartki - miejsca te sygnalizuję znakiem [...].

${ }^{35}$ M i c hał R e m b a c z (1854-1931) - inżynier, absolwent Politechniki Lwowskiej, profesor geometrii wykreślnej. Nauczyciel w szkołach Krakowa, Stanisławowa, Jarosławia; dyrektor szkoły realnej w Tarnopolu. W latach 1907-1914 dyrektor I Państwowej Szkoły Realnej we Lwowie. Zob. Z żałobnej karty. Ś. p. Michał Rembacz. „Przegląd Pedagogiczny” 1931, nr 7, z 21 II, s. 177.

${ }^{36}$ Trzydzieste sprawozdanie [...], s. 62, 76.

${ }^{37}$ Le on A leks ander S a pieha (1883-1944) - ziemianin, pilot, podróżnik (m.in. do 
Stanisław (z adnotacją „pryw[atysta]”) pojawia się pod numerem 14. Z innych maturzystów eksternistycznych Maria Królikowska uzyskała wyróżnienie (lokata 6), a Stanisław Niemczewski zamyka listę. Sprawozdanie informuje ponadto: „Poprawkę z jednego przedmiotu otrzymało 8 uczniów publicznych i 1 eksternista; reprobowano na rok dwóch eksternistów" ${ }^{38}$. Czy poprawkę miał właśnie Stanisław Ignacy Witkiewicz? Raczej nie, biorąc pod uwagę pozycję końcową, ale może poprawka anulowała ocenę $\mathrm{z}$ pierwszego egzaminu?

Zresztą sam maturzysta wydaje się zadowolony z wyniku, skoro dopisuje się na oddzielnej kartce do cioci Mery w cytowanym na początku artykułu liście ojca z 7 VI:

Kochana Ciociu! Wczoraj wróciłem ze Lwowa po skończonym szczęśliwie egzaminie „dojrzałości”. Mam nadzieję, że to mi zyska pewne większe poszanowanie w rodzinie, a co najważniejsze, że Ojczunio nie będzie mi żałował więcej konfitur. Jestem trochę zmęczony, ale mam nadzieję, że niedługo będę mógł się zabrać do roboty. Całuję Ciocię i Niunię bardzo serdecznie ${ }^{39}$.

Po kilkudniowym pobycie w Zakopanem Witkiewicz syn zaczyna zasłużone wakacje: jedzie na Podole, zwiedza Kamieniec, przez Kijów dociera do Syłgudyszek na Litwie (stamtąd śle list do Bronisława Malinowskiego), skąd wyprawia się nad morze, do Połągi. Po powrocie z wojaży poświęca czas na filozofię - pisze traktat Marzenia improduktywa - i studiuje wyższą matematykę ${ }^{40}$. Po 2 latach, uzbrojony w maturę, postanawia wstąpić w progi krakowskiej Akademii Sztuk Pięknych - ku rozpaczy i przy głośnych protestach ojca.

Czy egzamin dojrzałości pozostawił ślady w Witkacym? Wydaje się, że tak, ale są to ślady, których trzeba się dobrze naszukać, jak w przypadku tego dotyczącego opowiedzenia sztuki Irzykowskiemu własnymi słowami. W tematach maturalnych zwraca uwagę polecenie przetłumaczenia z języka francuskiego fragmentu podręcznika Jana Amborskiego (właściwie wypisów z tego języka) pt. Appendice, czyli wyrostek. Pamięć o owym wyrostku musiała być na tyle trwała, że Witkacy w końcu użył go w tytule książki o narkotykach: Nikotyna, Alkohol, Kokaina, Peyotl, Morfina, Eter + Appendix (Warszawa 1932). Z pewnością mógł skorzystać z bardziej powszechnego zamiennika - „,suplement”, ale dlaczego tego nie zrobił, wyłożył w tejże książce: „Szalenie lubię appendixy, dygresje, wyjaśnienia, dodatkowe wnioski i poprawki - tylko nie w portretach, a szczególniej na żądanie klienta - to jest wprost wykluczone" ${ }^{41}$.

Indii i Cejlonu w latach 1922-1924), poseł na Sejm. Naukę w gimnazjum (we Lwowie, w Chyrowie, a następnie w Poznaniu) przerwał, wstępując do 3-letniej austriackiej Akademii Marynarki Wojennej w Fiume (obecnie Rijeka). Opuścił ją w 1903 r. i wtedy zdał maturę we Lwowie. Zob. A. S z k 1 a rs k a - L o h m a n n o w a, Sapieha Leon. Hasło w: Polski słownik biograficzny, t. 35 (1994).

38 Trzydzieste sprawozdanie [...], s. 76. Por. informacje o wynikach egzaminów dojrzałości w szkole realnej we Lwowie zamieszczone w „Gazecie Lwowskiej” (1903, nr 144, z 26 VI, s. 4).

39 Zob. przypis $1 \mathrm{w}$ niniejszym artykule.

${ }^{40}$ Po latach S. I. W it k i e w i c z o swoim stosunku do matematyki wypowiadał się następująco (O znaczeniu filozofii dla krytyki. W: Bez kompromisu. Pisma krytyczne i publicystyczne. Zebrał, oprac. J. D e g 1 e r. Warszawa 1976, s. 257, przypis): „Sfera myśli, dla której mam najgłębszy podziw. Sam się nią zajmowałem rok po maturze i odżałować nie mogę, że nie skończyłem tego wydziału. Ale także niemożliwa jest jako codzienna tresura. - Wymaga zupełnego poświęcenia się na lata całe i specjalizacji”.

${ }_{41}$ S. I. W i t k i e w i c z, Narkotyki. - Niemyte dusze. Oprac. A. M i c iń s k a. Warszawa 1993, s. 140. Dzieła zebrane. [T. 12]. 
Więcej skojarzeń maturalnych przynosi lektura opublikowanej w 1930 roku (ukończonej 3 lata wcześniej) powieści Nienasycenie. Witkacy mimochodem niejako rozlicza się z maturą $\mathrm{w}$ inicjalnym zdaniu rozdziału pt. Tortiury i pierwszy występ , Gościa z dna”:

Zupełnie niewyspany, w straszliwym nieświadomym co do istoty swej kokainowym katzenjammerze (działy się wprost otchłanne cuda i objawienia. Skąd?), po całodziennych ćwiczeniach za miastem wśród nudnego jak matura pejzażu (był szary, ciepły, słodkawy, pachnący trawą dzień wiosenny), popędził Genezyp koło szóstej na ulicę św. Retoryka do Persy ${ }^{42}$.

Kto wie, może właśnie taką wiosnę zastał Stanisław Ignacy po przyjeździe do Snopkowa?

Jakże tu nie „babrać się w bebechach” autora (przypominam: określenie Witkacego, protestującego przeciw łączeniu biografii pisarza z jego dziełem), jeśli po lekturze sprawozdania z tematami maturalnymi czyta się fragment Nienasycenia, w którym Genezyp znajduje się w sytuacji tuż przed nieuchronnym stosunkiem seksualnym z księżną:

Czymże wobec tego były wszystkie egzaminy i matura nawet. Było to trudne jak rysunek z geometrii wykreślnej: jakiś cień rotacyjnego elipsoidu rzucony na graniastosłup przecinający się z ukośnym ostrosłupem. Zajęczał, zamyczał raczej jak krowa, z męki niewysłowionej, i to go ocaliło od pęknięcia ${ }^{43}$.

Pozostaje jeszcze wyjaśnić tytuł artykułu, zaczerpnięty ze sprawozdania z roku 1903. Kim był „prywatysta”? Dlaczego nie zwykły „ekstern”? Wyraz ów jest (był?) na tyle galicyjski, że już wyszedł z użycia - na próżno szukać go we współczesnych słownikach wyrazów obcych. Ale, jak zawsze, można liczyć na przedwojenny dykcjonarz Michała Arcta - nie ustanę w wyrażaniu wdzięczności Janowi Gondowiczowi za zwrócenie mi uwagi na to dzieło! - który podaje taką oto definicję ,prywatysty”:

uczeń prywatny, w Galicji uczeń, który uczęszczał na niektóre tylko albo i na wszystkie wykłady szkolne, ale nie otrzymywał urzędowego świadectwa postępów w nauce ${ }^{44}$.

Prywatysta Stanisław Ignacy Witkiewicz - ku zadowoleniu (choć tylko częściowemu) Stanisława Witkiewicza ojca.

Dziękuje Januszowi Deglerowi i Janowi Gondowiczowi za komentarze do artykulu.

\section{A b stract}

TOMASZ PAWLAK

(Warsaw)

\section{PRIVATE STUDENT WITKIEWICZ. \\ ON STANISŁAW IGNACY WITKIEWICZ’S HIGH SCHOOL FINALS}

The article describes Stanisław Ignacy Witkiewicz's high school finals taken in 1903. Prejudice of Stanisław Witkiewicz, the father of the later painter, writer, dramatist and philosopher, against the

${ }^{42}$ S. I. Witk i e w i c z, Nienasycenie. Oprac. J. D e g l e r, L. S o k ó ł. Warszawa 1992, s. 425. Dzieta zebrane. [T. 3].

43 Ibidem, s. 147.

${ }^{44}$ A r c t, op. cit., s. 281. 
institution of school influenced his decision of not letting his son to school. Young Witkiewicz, however, took his examinations as an extramural. The preserved correspondence of father to his son reveals numerous commentaries and remarks about the finals and expressions of concern for the examinee. As based on the found report on school activity in which the examination took place, examination tasks register and also pieces of information on the teachers working at this school, and first and foremost the father's letters to the son, the author of the article attempts at reconstructing the preparations to the examination as well as its course. The text is completed with references to the high school finals in mature S. I. Witkiewicz-Witkacy's literary and polemic creativity. 